\title{
KOMUNIKASI BUDAYA MELALUI PROSESI PERKAWINAN ADAT PADA SUKU BATAK TOBA
}

\section{CULTURAL COMMUNICATION THROUGH THE TRADITIONAL PROCESSION OF THE BATAK TOBA TRIBE}

\author{
Ruth Novelita ${ }^{1}$, Muhammad Luthfie ${ }^{2 *}$, Maria Fitriah ${ }^{3}$. \\ ${ }^{123}$ Program Studi Sains Komunikasi, Fakultas Ilmu Sosisal dan Ilmu Politik, Universitas Djuanda Bogor Jl. Tol Ciawi \\ No 1 Kotak Pos 35 Bogor 16720 \\ *Korespondensi: mluthfie@unida.ac.id
}

(Diterima oleh Dewan Redaksi: 01-08-2019)

(Dipublikasikan oleh Dewan Redaksi: 01-10-2019)

\begin{abstract}
Customary marriage procession in the Toba Batak tribe is a process that is carried out repeatedly. In the process of the traditional marriage of the Batak tribe there are several stages that must be passed to achieve a Batak community's recognition of the marriage. This study aims to analyze the communication process that occurs in the traditional marriage of the Batak Toba tribe. The research approach used is qualitative with descriptive method. Data collection is done by observation techniques, in-depth interviews, and documentation studies. The data analysis technique uses Miles and Huberman theories, namely data reduction, data presentation, and conclusion drawing. To check and compare the validity of the data using the source triangulation analysis technique.The results of the study show that the Batak culture community has high values of customs in the marriage of the Toba Batak tribe. This conclusion is evidenced that in the modern era, Batak culture communities still use traditional processes such as the process of marhata sinamot, and the process of mangulosi in the marriage of Batak culture.
\end{abstract}

Keywords: Cultural Communication; Traditional Ceremonies; Wedding Procession. 


\begin{abstract}
ABSTRAK
Prosesi perkawinan adat dalam suku batak toba merupakan proses yang dilakukan secara berulang-ulang. Dalam proses adat perkawinan suku Batak ada beberapa tahapan yang harus dilalui untuk mencapai suatu pengakuan masyarakat batak mengenai pernikahan tersebut. Penelitian ini bertujuan untuk menganalisis proses komunikasi yang terjadi dalam pernikahan adat suku batak toba. Pendekatan penelitian yang digunakan adalah kualitatif dengan metode deskriptif. Pengumpulan data dilakukan dengan teknik observasi, wawancara mendalam, dan studi dokumentasi. Adapun teknik analisis data menggunakan teori Miles dan Huberman yaitu reduksi data, penyajian data, dan penarikan kesimpulan.Untuk memeriksa dan membandingkan keabsahan data menggunakan teknik analisis triangulasi sumber. Hasil penelitian menunjukan bahwa masyarakat budaya Batak menjunjung tinggi nilai adat istiadat dalam pernikahan suku Batak Toba. setiap tahapan pernikahan yang dilakukan mengandung nilai-nilai kebudayaan Batak. Kesimpulan penelitian adalah era modern kini masyarakat budaya Batak masih menggunakan proses adat istiadat seperti proses marhata sinamot, dan proses mangulosi dalam pernikahan budaya Batak.
\end{abstract}

Kata Kunci: Komunikasi Budaya; Upacara Adat; Prosesi Pernikahan.

Ruth Novelita, 2019. Komunikasi Budaya Melalui Prosesi Perkawinan Adat Pada Suku Batak Toba. 


\section{PENDAHULUAN}

Kebudayaan diartikan sebagai tumpuan, kepercayaan, nilai, agama, makna, peran dan suatu hubungan yang memiliki ciri khas dan dimiliki sekelompok besar orang dari generasi ke generasi (Mulyana, 2009). Kebudayaan sangat erat dan selalu berhubungan dengan manusia dalam setiap kegiatan acara maupun kesehariannya, terutama pada kehidupan keluarga budaya Suku Batak.

Kebudayaan suku Batak sangat menjunjung tinggi adat istiadat yang diterapkan dalam kehidupannya masingmasing. Prinsip kebudayaan suku Batak berpacu pada "Dalihan Na Tolu" yang berfungsi untuk menentukan posisi, hak, kewajiban dan kedudukan seseorang dalam mengendalikan tingkah laku seseorang dalam kelompok (Marbun Hutapea, 1987). Semua kebudayaan membutuhkan restu dari setiap masing masing pihak keluarga, begitu juga dengan kebudayaan suku Batak. Akan tetapi kebudayaan Batak pada proses pernikahan bukan hanya membutuhkan restu melainkan turut ikut serta berperan dalam proses upacara adat pernikahan tersebut.

Berdasarkan hasil wawancara dengan Djuara Lubis pada tanggal 19 Maret 2019 menjelaskan bahwa kebudayaan adat Batak hingga kini masih memegang teguh tradisi upacara adat yang dilakukan dari zaman dahulu kala. Upacara adat diturunkan kepada setiap generasi kini masih dipergunakan dalam setiap acara suku Batak. Hal ini dibuktikan dengan masih berjalan prosesi upacara adat pernikahan suku Batak yaitu: Marsitandaan, Marhorihori Dinding, Marhusip, Marhata Sinamot, Martumpol, Martonggo Raja, Pasu-pasu, dan Mangadati kepada pasangan yang ingin menikah. Dengan adanya Upacara adat Budaya Batak pengantin perempuan telah sah menjadi bagian dari keluarga pengantin laki-laki dan sah diakui masyarakat suku Batak.
Komunikasi adalah salah satu bagian dari hubungan antar manusia baik individu maupun dalam kehidupan sehari-hari (Effendy, 1986). Untuk melaksanakan sebuah pernikahan tentu tidak lepas dari proses komunikasi budaya yang dibangun oleh kedua keluarga proses tersebut dilakukan secara berulang-ulang hingga membentuk pola komunikasi budaya yang sesuai dengan prinsip Dalihan $\mathrm{Na}$ Tolu (Duranti, 2000). Bagi kebudayaan suku Batak proses komunikasi saling bertukar pikiran antar individu menghasilkan timbal balik tentu sangat diperlukan untuk mencapai tujuan atau kesepakatan bersama (Effendy, 1989).

Penelitian ini berkesinambungan dengan Kusumadinata (2015) yang berjudul proses enkulturasi dalam Budaya. Penelitian ini menunjukan bahwa upacara adat masyarakat tengger dibagi menjadi dua yaitu ruang lingkup keluarga dan ruang lingkup desa. Ini terbentuk dari Pola komunikasi yang digunakan bersifat vertikal, pola komunikasi ini terbawa dalam proses komunikasi kehidupan keluarga, dimana peran keluarga cukup besar dan masih kuatnya penghormatan pada generasi yang lebih tua pada masyarakat tengger.

Pernikahan kebudayaan suku Batak merupakan pernikahan eksogami, pernikahan yang hanya boleh dilakukan dengan sepasang pengantin yang memiliki nama marga yang berbeda hal ini sejalan dengan pendapat (Vergouwen, 1986). Eksogami tersebut mencegah terjadinya pernikahan satu marga atau satu garis keturunan. Proses upacara adat pernikahan suku Batak adalah proses yang dilakukan secara berulang-ulang. setiap tahap-tahap mengandung simbol, nilai atau makna kebudayaan seperti proses mangulosi dan proses marhata sinamot yang berhubungan dengan hasil proses komunikasi yang dilakukan. 
Berdasarkan latar belakang dapat dirumuskan masalah yaitu bagaimana proses komunikasi budaya yang terjadi dalam rangkaian prosesi pernikahan suku Batak Toba.

\section{MATERI DAN METODE}

Metode penelitian yang digunakan dalam penelitian ini adalah metode dengan pendekatan kualitatif. Metode deskriptif digunakan penulis untuk memberikan gambaran tentang prosesi perkawinan adat suku Batak.

Unit analisis pada penelitian ini adalah tahapan-tahapan proses upacara adat kebudayaan suku Batak. Untuk memperoleh data primer penulis menggunakan teknik observasi, sedangkan untuk mendapatkan data sekunder penulis melakukan wawancara mendalam dan studi dokumentasi. Uji Validitas data dilakukan dengan teknik triangulasi sumber.

Prosesi perkawinan pada suku Batak Toba, penulis menggunakan analisis Miles and Huberman (2006) yang terbagi menjadi tiga tahap yaitu reduksi data, penyajian data, dan penarikan kesimpulan. Pada tahap pertama reduksi data dilakukan proses pemilihan dan penyederhanaan data selama penelitian. Pada tahap kedua penyajian data dilakukan penyusunan seluruh data atau informasi secara sederhana yang kompleks sehingga membentuk analisis yang mudah dipahami. Pada tahap ketiga dengan melihat tahap pertama yang mengacu atau sesuai rumusan masalah dan tujuan penelitian yang telah disusun kemudian dibandingkan dengan data lain, sehingga dapat memperoleh penarikan kesimpulan secara menyeluruh.

\section{HASIL DAN PEMBAHASAN \\ A. Prosesi pernikahan adat suku Batak}

Sebagaimana disebutkan pada babbab, bahwa tujuan penelitian ini adalah menganalisis pola komunikasi pada prosesi pernikahan suku batak toba. Untuk mengetahui apa saja rangkaian upacara adat yang dilakukan dalam perkawinan suku batak toba. Penelitian ini sejalan dengan pendapat yang disampaikan oleh Ahmad (2007) dan Heriyanti (2002) mengenai pernikahan membutuhkan persetujuan kedua belah pihak yang mencangkup hubungan dengan masyarakat. Pada kebudayaan Batak dalam melangsungkan pernikahan sesuai harus mendapatkan izin dari dua keluarga besar, seperti pada prinsip dasar kebudayaan Batak "Dalihan Na Tolu" yaitu:

1. HULA-HULA merupakan kedudukan tertinggi yang sangat dihormati sikap hormat harus dijunjung tinggi untuk hula-hula.

2. Dongan Tubu merupakan teman semarga seperkumpulan, dongan tubu dilihat berdasarkan garis keturunan ayah atau marga ayah.

3. Boru merupakan pihak yang melayani, membantu dalam setiap kegiatan adat budaya Batak. Ada istilah "elek marboru" yaitu menyayangi atau membujuk pihak boru".

Kebudayaan Batak sangat menjunjung tinggi prinsip "dalihan na tolu" karena prinsip ini sangat mengutamakan suatu sikap hormat dan saling menghargai dan menyayangi antar masyarakat Batak. Dengan ajaran dalihan na tolu budaya Batak dapat mencapai suatu aspek Hagabeon (berketurunan), Hasangapon (kehormatan). Ini sangat sejalan dengan Panggabean (2017) yang menyampaikan bahwa dalihan na tolu sebagai tumpuan tatanan hidup seseorang yang berkaidah pada moral utama, sikap perilaku yang baik.

Proses komunikasi dalam pewarisan nilai budaya diwariskan dari setiap generasi melalui proses komunikasi atau disebut enkulturasi (Kusumadinata, 2015). Kebudayaan memiliki identitasnya masing-masing, identitas yang dimiliki budaya Batak adalah Marga. Dengan marga masyarakat Batak akan mengetahui silsilah keturunannya, dan identitas dirinya. Hal ini 
sejalan dengan pendapat yang disampaikan oleh ahli budaya Djuara Lubis pada wawancara 19 Maret 2019 yang menyampaikan bahwa identitas kebudayaan suku Batak adalah Marga. Seperti yang disampaikan Marbun Hutapea (1987) bahwa system marga yang amat luhur sebagai satu kekuatan untuk mempersatukan hubungan kekeluargaan dalam kebudayaan Batak.

Pernikahan Budaya Batak ada proses-proses yang harus dilakukan sebelum sah menjadi suami dan istri yaitu:

1. MARSITANDAAN merupakan perkenalan pertama kedua belah pihak.

2. MARHORI-HORI DINDING yaitu berbisik-bisik. Dalam tahap ini bertemunya kedua keluarga untuk membahas rencana pernikahan kedepan.

3. MARHUSIP yaitu pembicaraan rencana pernikahan kembali, disini hadir Bapakuda, atau kebabat dekat kedua keluarga. Tahapan ini sudah terjadi kesepakatan kedua keluarga untuk dibicarakan pada tahap marhata sinamot.

4. MARHATA SINAMOT yaitu bertemu kembali kedua keluarga untuk meberitahu dan menyepakati jumlah sinamot. Tahapan ini hadir seluruh keluarga besar kedua belah pihak termaksud dongan tubu turut serta dalam proses sinamot diberikan "uang ingot-ingot" untuk mengingatkan kembali tanggal pernikahan dan jumlah sinamot yang telah disepakati.

5. Martupol yaitu pertunangan kedua mempelai. Pertunangan tersebut dilakukan dibawah tangan gereja.

6. Martonggo Raja yaitu diskusi masingmasing pihak keluarga untuk membagibagi tugas untuk menghadapi pernikahan pada hari H. Tahapan ini dilakukan setelah proses matupol yang kemudian membentuk dua kubu keluarga untuk martonggo raja.

7. Pasu-Pasu yaitu pemberkatan nikah kedua mempelai. Pasu-pasu dilakukan di Gereja dan dihadiri tamu undangan. Pada proses ini hanya berlangsung sekitar dua jam.

8. Mangadati yaitu tahapan pernikahan terakhir tahap memberikan adat kepada pengantin. Pada tahap ini ada adat yang dilakukan yaitu proses "mangulosi" atau pemberian ulos. Pemberian ulos merupakan ciri khas Kebudayaan Batak, ulos diartikan sebagai bentuk kasih sayang si pemberi kepada si penerima. Ulos yang diberikan dalam upacara adat pernikahan itu Ulos Holong. Dalam proses mangadati juga dilakukan proses pembagian jambar (membagikan daging) ini bertujuan sebagai ungkapan terima kasih yang mempunyai pesta kepada para tamu undangan (kerabat keluarga).

Sebagai penutup acara Upacara adat semua tamu undangan mengucapkan "Horas" sebanyak tiga kali. Maka selesailah rangkaian pesta perkawinan sekaligus upacara adat itu. Upacara adat telah selesai dilakukan berarti pernikahan tersebut dianggap telah sah dimata hukum adat. Akhir acara ditutup dengan doa bersama dan nyanyian dengan tarian tor-tor "manontor" (acara hiburan).

\section{B. Pemaknaan prosesi pernikahan suku Batak Toba}

Pernikahan Budaya Batak terdapat proses komunikasi yang menghasilkan pemaknaan dari beberapa tahapan dalam melakukan upacara adat pernikahan budaya Batak sebagai berikut:

1. Sinamot: Menunjukan kemampuan dan harga diri dari pihak keluarga laki-laki kepada pihak keluarga perempuan.

2. Sibuha-buhai: Makan bersama memohon agar acara adat dapat berjalan dengan lancar.

3. Acara penyambutan: Sebagai pemaknaan sukacita penerimaan pihak perempuan kepada pihak laki-laki.

4. Pemberian beras dan dekke: Wujud gotong royong untuk mensukseskan acara bahwa pihak keluarga laki-laki 
dan pihak keluarga perempuan telah bersatu menjadi keluarga.

5. Pemberian daging jambar: Memiliki makna memberikan kebahagiaan dan kemakmuran kepada pihak keluarga perempuan agar tenang, bahwa pihak keluarga laki-laki memberikan kebahagian kepada anaknya. Dan mewujudkan rasa syukur kepada Tuhan dan berbagi kesenangan.

6. Manotor: Wujud kegembiraan.

7. Mangulosi: Wujud sebagai rasa kasih sayang si pemberi kepada si penerima dengan penuh pengharapan, doa, suka cita. Pemberian ulos merupakan pelindung pernikahan si pemakai (pengantin).

\section{KESIMPULAN DAN IMPLIKASI}

Kesimpulan

1. Prosesi pernikahan budaya Batak memiliki sembilan taha- pan yaitu Marsitandaan (perkenalan kedua belah pihak), marhori-hori dinding(berbisikbisik), Marhusip (pembicaraan pernikahan menyangkut orang tua), Marhata Sinamot (transaksi yang diberikan pihak laki-laki kepada wanita untuk melakukan pernikahan), Martupol(tunangan).Martonggo Raja (diskusi keluarga masing-masing untuk mempersiapkan segala sesuatu menghadapi pesta pernikahan/ pembagian perkerjaan), Pasu -Pasu (pemberkatan nikah), dan Mangadati (memberi adat kepada pasangan yang melakukan penikahan).

2. Prinsip utama "Dalihan $\mathrm{Na}$ Tolu" merupakan tumpuan hidup masyarakat Batak. Prinsip tersebut mengandung elemen untuk mengatur dan mengendalikan sikap perilaku seseorang dalam suatu perkumpulan kelompok budaya Batak, yaitu Hulahula, Dongan Tubu, dan Boru. Prinsip tersebut untuk mencapai hagabeon (keturunan), hasangapon (kehormatan), hamoraon (kekayaan).
3. Pola komunikasi multi arah mengatur proses komunikasi menyeluruh kepada semua individu dalam kelompok budaya Batak yang sesuai dengan prinsip dalihan na tolu. Akan tetapi proses adat pernikahan mengalami sedikit perubahan yaitu proses tahapan marsitandaan dan tahapan marhori-hori dinding kini disatukan menjadi satu pertemuan.

\section{IMPLIKASI TEORITIS DAN PRAKTIS}

Kebudayaan mempengaruhi komunikasi. Hal ini sesuai dengan (Poter dan Samovar, 1993) dengan budaya individu dapat berkomunikasi. Komunikasi menghasilkan simbol non verbal seperti penggunaan ulos "mangulosi" sesuai dengan (Alex Sobur, 2004).

\section{DAFTAR PUSTAKA}

Duranti, Alessandro. 2000. Linguistic Anthropology. United Kingdom: Cambridge University Press.

Effendy, OnongUchyana, 1986, Dinamika Komunikasi, Rosdakarya Bandung.

Effendy, Onong Uchjana. 1989. KAMUS KOMUNIKASI. Bandung :PT. Mandar Maju.

Kusumadinata. 2015. Proses Enkulturasi Dalam Budaya. Jurnal Komunikatio 1(1): 21.

Marbun. M.A. dan Hutapea. I. M. T. 1987. Kamus Budaya Batak Toba. Jakarta: Balai Pustaka.

Mulyana, Deddy. 2009. Ilmu komunikasi; suatu pengantar. Bandung: Remaja Rosdakarya.

Panggabean, 2017. Revitalisasi penerapan hukum adat Batak.

Vergouwen, J.C. 1986. Masyarakat dan Hukum Adat Batak Toba. Cetakan I. Jakarta: Terjemahan Pustaka Azet. 